\title{
In memoriam Wilfried de Jong (1942 - 2016)
}

\author{
Peter Bloemers $^{1} \cdot$ Wilbert Boelens ${ }^{1}$
}

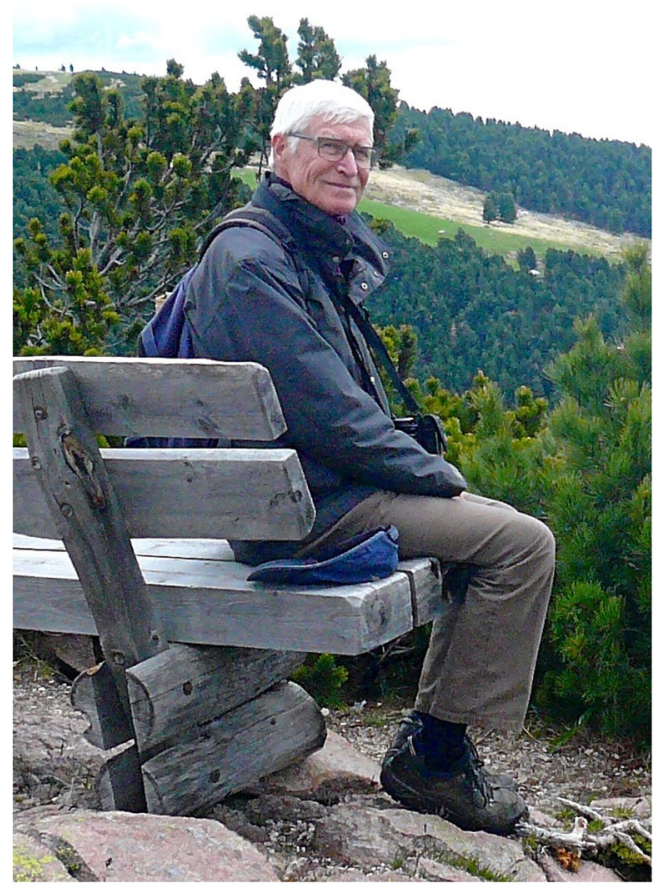

On April 11, 2016 Wilfried de Jong, professor emeritus of Biochemistry at the Radboud University (The Netherlands), passed away. De Jong was a prominent biochemist with his extensive scientific work in the field of protein chemistry and

Wilbert Boelens

W.Boelens@ncmls.ru.nl

1 Biomolecular Chemistry, 284, Radboud University, PO Box 9101, 6500 HB Nijmegen, The Netherlands molecular evolution. In both fields, he can be considered a pioneer, whose work was an inspiration for a large group of undergraduate and $\mathrm{PhD}$ students. His work has been reported in about 230 publications. He received the Alcon Research Institute Annual Award 1989 for excellent research on lens proteins and was editor of four journals in the field of eye research and molecular evolution. In recognition of his outstanding contributions to understanding the molecular phylogenetics among the main mammalian lineages, the species name of the Madagascar frog, Blommersia deJongi, was dedicated to him.

Wilfried de Jong was born in Sneek in 1942. He studied biology in Utrecht, where he obtained his Master's degree in 1965 with honors, followed by his $\mathrm{PhD}$ in 1969 at Leiden University, also with honors. His doctoral work was focused on mutations in human hemoglobin. After a sabbatical at Stanford (Department of Genetics) he returned in 1970 to Leiden and moved to Nijmegen one year later, where he became the closest collaborator of Hans Bloemendal. There he began his research on eye lens proteins and became an international expert in this field. Besides his work in Nijmegen, he was adjunct professor of molecular systematic zoology from 1993 until 2006 at the University of Amsterdam.

Francis Crick, the main founder of molecular biology, in his visionary article 'On Protein Synthesis' predicted in 1957 that even evolutionary family trees would be derived from amino acid sequences; pure science fiction as it seemed then. But less than twenty years later, it was exactly what was done by Wilfried de Jong with the slowly evolving lens proteins. When it became clear that many of the eye lens crystallin proteins were in the course of evolution co-opted from other functions, Wilfried de Jong attained a prominent position in this field of research as well. The $\alpha$-crystallins A and B 
turned out to be so-called small heat shock proteins (sHSPs) with roles as chaperone proteins to protect the native conformation of other proteins after their production and under special circumstances such as stress (e.g., heat, lack of oxygen or aging). Based on sequence similarity he found that humans have 10 different sHSPs, called HspB1 - 10. When an eleventh sHSP was sug- gested, merely based on functional similarities, he was strongly opposed, arguing that a real protein family may only contain evolutionarily related proteins.

With the passing of Wilfried de Jong, we have lost a modest and erudite biochemist with a sense of humor and a sense of perspective, and above all, we have lost a good friend and colleague. 